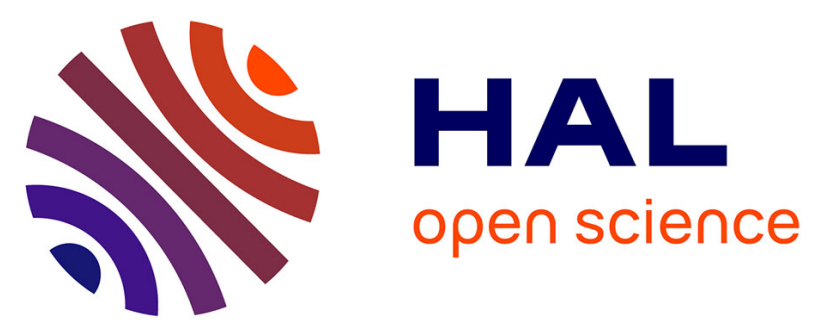

\title{
Celecoxib and exemestane versus placebo and exemestane in postmenopausal metastatic breast cancer patients: a double-blind phase III GINECO study
}

C. Falandry, M. Debled, Thomas Bachelot, T. Delozier, J. Crétin, P. Romestaing, D. Mille, Benoit You, L. Mauriac, E. Pujade-Lauraine, et al.

\section{To cite this version:}

C. Falandry, M. Debled, Thomas Bachelot, T. Delozier, J. Crétin, et al.. Celecoxib and exemestane versus placebo and exemestane in postmenopausal metastatic breast cancer patients: a doubleblind phase III GINECO study. Breast Cancer Research and Treatment, 2008, 116 (3), pp.501-508. 10.1007/s10549-008-0229-5 . hal-00478277

\section{HAL Id: hal-00478277 https://hal.science/hal-00478277}

Submitted on 30 Apr 2010

HAL is a multi-disciplinary open access archive for the deposit and dissemination of scientific research documents, whether they are published or not. The documents may come from teaching and research institutions in France or abroad, or from public or private research centers.
L'archive ouverte pluridisciplinaire HAL, est destinée au dépôt et à la diffusion de documents scientifiques de niveau recherche, publiés ou non, émanant des établissements d'enseignement et de recherche français ou étrangers, des laboratoires publics ou privés. 


\title{
Celecoxib and exemestane versus placebo and exemestane in postmenopausal metastatic breast cancer patients: a double-blind phase III GINECO study
}

\author{
C. Falandry $\cdot$ M. Debled $\cdot$ T. Bachelot $\cdot$ T. Delozier · \\ J. Crétin $\cdot$ P. Romestaing $\cdot$ D. Mille $\cdot$ B. You $\cdot$ \\ L. Mauriac $\cdot$ E. Pujade-Lauraine $\cdot$ G. Freyer
}

Received: 22 August 2008/ Accepted: 15 October 2008/Published online: 20 November 2008

(C) Springer Science+Business Media, LLC. 2008

\begin{abstract}
The aim of this study was to evaluate antitumor effects of cyclooxygenase-2 inhibitors in breast carcinoma and their ability to act synergistically with aromatase inhibitors (AIs). Postmenopausal metastatic breast cancer patients without previous adjuvant AI treatment received exemestane $25 \mathrm{mg}$ /days plus either celecoxib $400 \mathrm{mg}$ twice daily or placebo. The primary endpoint was progression-free survival (PFS). This trial was prematurely terminated ( $N=157$ of 342 planned) after cardiovascular toxicity was reported in other celecoxib trials. Although no PFS difference was observed between the two arms
\end{abstract}

C. Falandry · G. Freyer $(\bowtie)$

Université de Lyon, 69003 Lyon, France

e-mail: gilles.freyer@chu-lyon.fr; claire.falandry@chu-lyon.fr

C. Falandry · P. Romestaing $\cdot$ B. You - G. Freyer

Centre Hospitalier Lyon Sud, Hospices Civils de Lyon,

Pierre-Bénite, France

M. Debled · L. Mauriac

Institut Bergonié Regional Cancer Centre, Bordeaux, France

T. Bachelot

Centre Léon Bérard, Lyon, France

T. Delozier

Centre Francois Baclesse, Caen, France

J. Crétin

Clinique Valdegour, Nîmes, France

J. Crétin

Clinique Bonnefon, Alès, France

D. Mille

Institut de Cancérologie de la Loire, Saint Priest en Jarez, France

E. Pujade-Lauraine

Hôpital Hôtel-Dieu, Paris, France
(9.8 months for both, $P=0.72$ ), a trend favoring celecoxib was observed in 60 tamoxifen-resistant patients (9.6 vs. 5.1 months; $P=0.14$ ) and in 126 patients treated $\geq 3$ months before study termination (12.2 vs. 9.8 months; $P=0.09)$. No severe adverse events were reported. Cyclooxygenase-2 inhibitors seemingly contribute to reverse endocrine resistance in breast cancer patients, although further study is necessary to allow development of a new therapeutic strategy.

Keywords Breast cancer - Celecoxib - Exemestane . Aromatase $\cdot$ Cyclooxygenase- $2 \cdot$ Clinical trial

\section{Introduction}

Despite intensive efforts in cancer control, breast cancer remains the second leading cause of cancer death in western countries $[1,2]$. In the metastatic setting, it is widely accepted that the main objective is to maintain good quality of life for patients as long as possible [3]. For the majority of patients with hormone receptor-positive, slowly progressing tumors, endocrine therapy appears to be the treatment of choice [4-6]. For postmenopausal women, hormone therapy with an aromatase inhibitor (AI) is a standard first-line treatment for women who were not treated with an $\mathrm{AI}$ in the adjuvant setting, although median time to progression for these patients is $\sim 8-11$ months, with no demonstrated survival advantage over tamoxifen [7-10]. Consequently, to increase the therapeutic benefit of hormone therapy, new approaches are still needed.

Prostaglandins can enhance carcinogenesis by inducing cell proliferation, suppressing apoptosis, stimulating angiogenesis and invasiveness, and inhibiting immune responses [11-15]. Prostaglandin synthesis from arachidonic acid is 
mediated by cyclooxygenase (COX)- 1 and COX-2 isoenzymes. Most tissues that normally produce prostaglandins have constitutive expression of COX-1 [16], whereas COX2 expression is induced by mitogens, hormones, serum, and cytokines [16], leading to localized acute inflammatory responses. COX-2 expression is also upregulated in some human premalignant and malignant pathologies [17], including breast cancer [18]. Moreover, transgenic mice that overexpress human COX-2 in mammary glands develop focal mammary gland hyperplasia, dysplasia, and metastatic tumors [19]. In contrast, tumor-prone MMTV/neu mice that were made to be COX-2-deficient develop fewer, smaller tumors with substantially reduced vascular infiltration than mice expressing COX-2 [20]. Thus, COX-2 has become an attractive target for inhibiting tumor growth.

Nonsteroidal anti-inflammatory drugs (NSAIDs) that are not selective for COX-2, such as ibuprofen and aspirin, have demonstrated therapeutic potential against breast cancer in an epidemiologic case-control study [21]. In addition, celecoxib analogs, some of which are selective COX-2 inhibitors, were shown to be potent inhibitors of phospho-Akt-signaling pathways and to induce apoptosis in breast cancer cells in vitro [22,23]. Studies with animal models of breast cancer have demonstrated that treatment with selective COX-2 inhibitors reduced the formation, growth, microvasculature, and metastases of tumors [13, 23-26]. Furthermore, selective COX-2 inhibitors have been shown to reduce the number of intestinal tumors in patients with familial adenomatous polyposis [27, 28].

Despite the inability to correlate increased COX-2 expression with upregulated hormone receptors, COX-2 overexpression leads to a proximal activation of the aromatase gene [29]. AIs and COX-2 inhibitors were shown to have a synergistic antitumor activity in a rat model of mammary carcinoma [30], and the association has also been tested in clinical trials, in both adjuvant and metastatic settings, with promising preliminary results in limited numbers of patients [31-33].

The aim of this study was to compare the efficacy of the combination of the AI exemestane and the COX-2 inhibitor celecoxib with exemestane + placebo in a first-line metastatic setting in postmenopausal women with hormone receptor-positive breast cancer.

\section{Methods}

\section{Patients}

Postmenopausal women with estrogen receptor- and/or progesterone receptor-positive metastatic breast cancer with measurable lesions $>1 \mathrm{~cm}$ in diameter were eligible for enrollment. Inclusion criteria included an Eastern
Cooperative Oncology Group performance status $\leq 2$ and adequate hematologic, renal, and hepatic function (serum bilirubin $\leq 2 \times$ upper limit of normal [ULN], alanine aminotransferase and aspartate aminotransferase $\leq 2 \times$ ULN or $\leq 4 \times$ ULN if hepatic metastases, alkaline phosphatase $\leq 2 \times$ ULN or $\leq 5 \times$ ULN if hepatic metastases). Patients with isolated bone metastases with typical radiologic lesions and an associated increase in cancer antigen (CA) 15-3 were eligible, but not patients with isolated CA 15-3 increases. Exclusion criteria included prior adjuvant treatment with an AI; endocrine therapy for metastatic cancer; and ongoing treatment with an NSAID, fluconazole, lithium, or warfarin. Patients with an allergy to NSAIDs, an uncontrolled cardiac comorbidity (e.g., angina or congestive heart failure), or a history of myocardial infarction within 3 months were also excluded. However, previous chemotherapy for metastases was permitted.

Study design

This was a multicenter, double-blind, randomized phase III study conducted at 62 sites in France. The study, sponsored by Pfizer Inc, was conducted independently by the Groupe d'Investigateurs Nationaux pour l'Etude des Cancers de l'Ovaire et du Sein (GINECO) according to the principles of the Declaration of Helsinki, and the protocol was approved by the Independent Ethics Committee of Paris Hôtel Dieu Hospital. All patients provided written informed consent. At study entry, patients underwent baseline evaluations that included a complete medical history and physical examination; assessment of performance status; and biologic evaluation of CA 15-3 levels and hematologic, renal, and hepatic functions. Standard radiologic screening at baseline included computed tomography scans of the chest, abdomen, and pelvis and a bone scan. All patients received exemestane $25 \mathrm{mg}$ daily. In addition, patients were randomly assigned to receive celecoxib $800 \mathrm{mg}$ (400 mg twice daily) or placebo. No dose reductions were planned. Randomization was performed by stratified block permutation. Stratification was done according to the center, previous chemotherapy for metastatic disease, and presence of visceral lesions. Physical examinations were performed, symptoms and/or adverse events (using the National Cancer Institute Common Toxicity Criteria Version 2.0) were assessed, hematology and blood chemistry profiles including CA 15-3 were obtained, and tumor response was monitored every 2 months. A complete set of imaging tests was planned at 2 months, every 6 months thereafter and whenever clinically indicated.

Statistical analysis

The primary study endpoint was progression-free survival (PFS). Secondary objectives included assessments of tumor 
response and toxicities. A minimum of 171 patients per treatment group with a minimum follow-up of 1 year were required to provide $90 \%$ power to detect a difference in PFS at 1 year of $15 \%$ (from 35 to $50 \%$ ) with a 2 -sided significance of $5 \%$. PFS was measured from the date of study enrollment to clinical or radiologic progression or death, or censored at date of last contact. Analyses for efficacy were performed on the intent-to-treat population on a per-protocol basis. Efficacy was assessed by the treating physician and was systematically reassessed by a review panel following Response Evaluation Criteria in Solid Tumors (RECIST) guidelines. No intermediate analysis was planned; however, because of the premature termination of the study, a supplementary analysis of the patients who were enrolled $\geq 3$ months before study termination was also performed. The subgroup of patients with tamoxifen-resistant disease (defined as relapse during or within 12 months of completion of tamoxifen therapy) was also assessed.

Progression-free survival was analyzed using KaplanMeier analysis, and the predictive role of pretreatment covariates was estimated in univariate analysis, using logrank tests. Response rates were compared using the Fisher exact test. For toxicity comparisons, the Mann-Whitney $U$ test could be supplemented with the Fisher exact test for values with normal distribution. Statistical analysis was independently performed.

\section{Results}

Patients

Because of notification in December 2004 of cardiovascular toxicities in other trials with celecoxib [34], the sponsor of this trial decided to terminate the study prematurely. Between September 2003 and December 2004, 157 patients were enrolled in 27 centers. Patient characteristics at baseline were well balanced between treatment groups (celecoxib + exemestane, $n=74$; placebo + exemestane, $n=83$; Table 1 ). Although slightly more patients in the placebo group had multiple metastases and visceral disease at study entry, these differences were not significant $(P=0.77,0.20$, respectively). The median duration of treatment was 5.8 months (6 months celecoxib vs. 5.6 months placebo, $P=0.6$ ). At the time of the sponsor's decision to terminate the study, 85 patients were still receiving treatment (celecoxib, $n=43$; placebo, $n=42$ ). The administration of celecoxib and placebo was stopped, but treatments were not unblinded; exemestane monotherapy was continued until disease progression was observed. Before study termination, 31 and 41 patients had discontinued treatment in the celecoxib and placebo arms,
Table 1 Patient demographics

\begin{tabular}{|c|c|c|c|}
\hline Characteristic & $\begin{array}{l}\text { Celecoxib + } \\
\text { exemestane }\end{array}$ & $\begin{array}{l}\text { Placebo }+ \\
\text { exemestane }\end{array}$ & $P$ value \\
\hline Patients, $n$ & 74 & 83 & \\
\hline \multicolumn{4}{|l|}{ Age (years) } \\
\hline Median & 61 & 63 & \\
\hline Range & $38-84$ & $37-82$ & \\
\hline \multicolumn{4}{|l|}{ Hormone receptor status $(\%)$} \\
\hline $\mathrm{ER}+$ and/or $\mathrm{PgR}+$ & 93 & 94 & 0.44 \\
\hline HER $2+$ & 4 & 5 & 0.83 \\
\hline Adjuvant chemotherapy (\%) & 45 & 53 & 0.34 \\
\hline Adjuvant tamoxifen (\%) & 57 & 61 & 0.63 \\
\hline Performance status (\%) & & & $0.34 *$ \\
\hline 0 & 50 & 43 & \\
\hline 1 & 41 & 47 & \\
\hline 2 & 7 & 10 & \\
\hline Unknown & 3 & 0 & \\
\hline \multicolumn{4}{|l|}{ Metastatic site $(\%)$} \\
\hline Visceral & 37 & 47 & 0.20 \\
\hline Liver & 20 & 19 & 1.00 \\
\hline Lung/pleura & 18 & 29 & 0.13 \\
\hline Lymph node & 26 & 25 & 1.00 \\
\hline Soft tissue & 14 & 10 & 0.67 \\
\hline Bone (isolated) & 35 & 41 & 0.49 \\
\hline \multicolumn{2}{|l|}{ Number of metastatic sites (\%) } & & $0.78 *$ \\
\hline 1 & 67 & 56 & \\
\hline 2 & 22 & 30 & \\
\hline$>2$ & 14 & 14 & \\
\hline
\end{tabular}

respectively. Eleven patients discontinued treatment because of toxicity (celecoxib, $n=5$; placebo, $n=6$ ). Patient disposition and reasons for discontinuation are shown in Fig. 1.

\section{Efficacy}

Of 157 patients enrolled in the study, 146 were evaluable for disease response and 140 were reassessed by a review panel. The median follow-up was 24 months, and the median PFS in the intent-to-treat analysis was the same in both treatment groups (9.8 months, $P=0.72$; Fig. 2a). Although the difference was not significant, PFS appeared to be numerically longer for patients receiving celecoxib compared with those receiving placebo in the subgroup of tamoxifen-resistant patients [9.6 months $(n=29)$ vs. 5.1 months $(n=31)$ ], respectively; $P=0.14$; Fig. $2 \mathrm{~b})$; a similar trend favoring patients in the celecoxib arm was also 
Fig. 1 Patient disposition

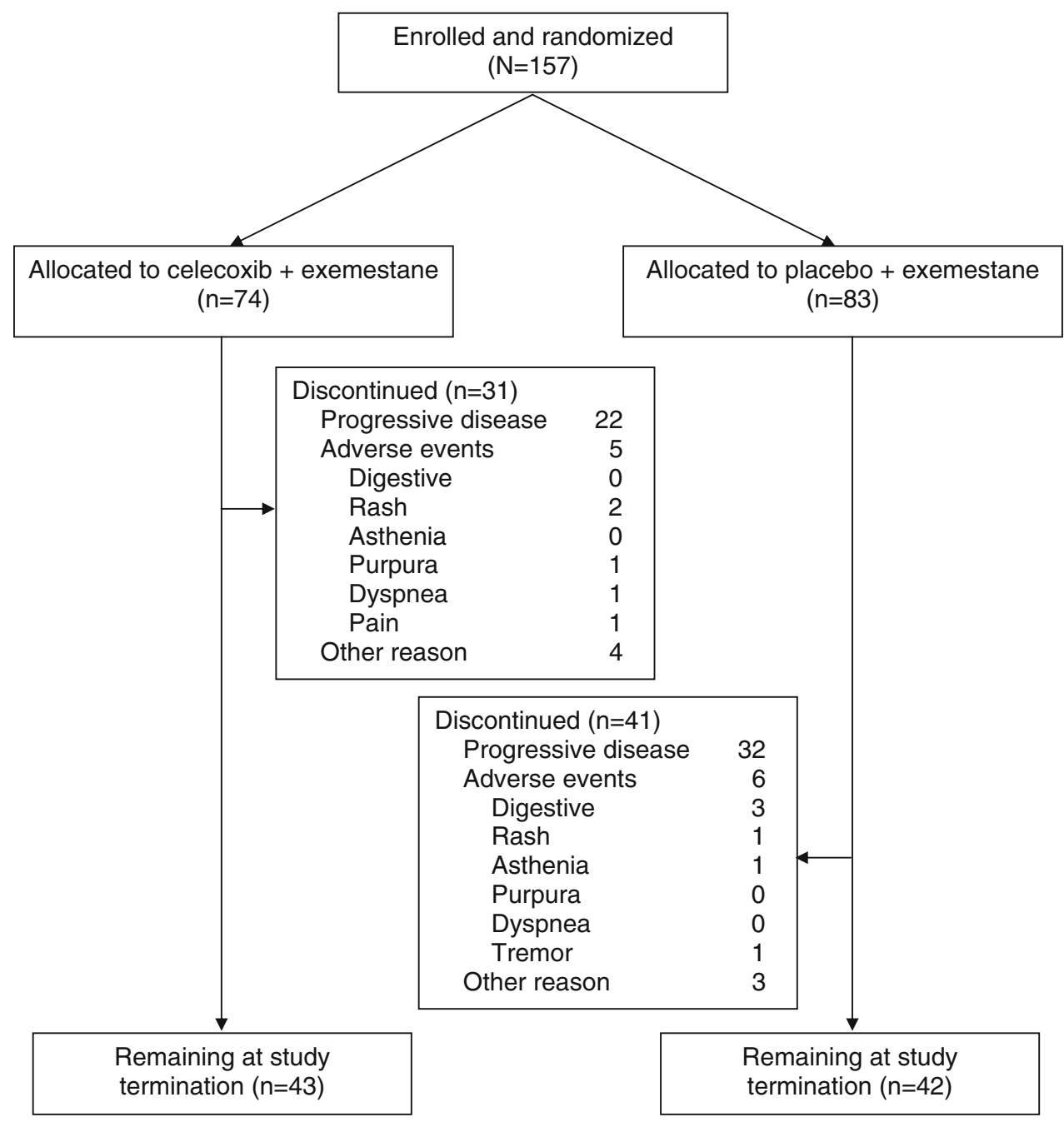

Fig. 2 Progression-free survival. a Intent-to-treat population $(n=157)$. b Patients resistant to adjuvant tamoxifen $(n=60)$. Resistance is defined as relapse while being treated with tamoxifen or within 1 year after completion of treatment
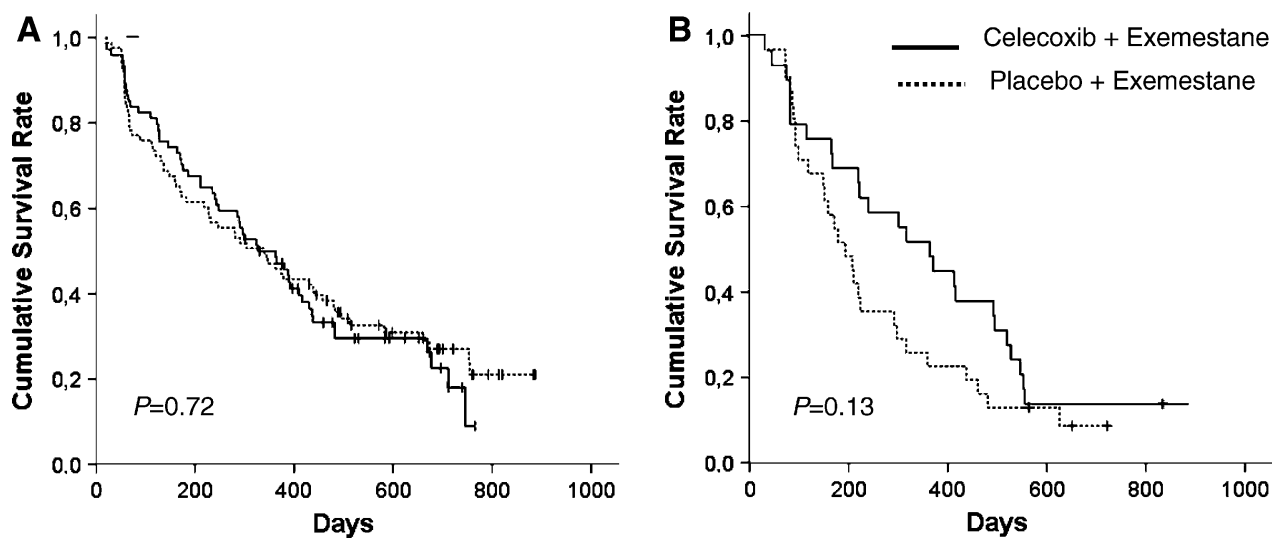

observed in the subgroup of patients treated $\geq 3$ months before the termination of the study [12.2 months $(n=56)$ vs. 9.8 months $(n=70)$, respectively; $P=0.09]$. The PFS difference between the celecoxib and placebo arms was significant in tamoxifen-resistant patients treated for $\geq 3$ months [8.4 months $(n=21)$ vs. 4.7 months $(n=21)$, respectively; $P=0.019$ ]; this subgroup analysis was not preplanned. Based on RECIST guidelines, the difference in response rate assessed by a review panel was not statistically significant ( $24 \%$ vs. $17 \%, P=0.18$; (Table 2). Disease progression was observed in 22 (30\%) and 32 (39\%) patients in the celecoxib and placebo groups, respectively $(P=0.236)$, with median durations of response of 5.8 months and 4.1 months $(P=0.250)$. 
Table 2 Overall response rate

\begin{tabular}{lclc}
\hline & $\begin{array}{l}\text { Celecoxib }+! \\
\text { exemestane, } \\
n(\%)\end{array}$ & $\begin{array}{l}\text { Placebo }+ \\
\text { exemestane, } \\
n(\%)\end{array}$ & $P$ value \\
\hline Overall response rate & $15(24)$ & $13(17)$ & 0.18 \\
Complete & $1(2)$ & $0(0)$ & \\
Partial & $14(23)$ & $13(17)$ & \\
Stable disease & $34(55)$ & $44(56)$ & \\
\hline
\end{tabular}

Safety

Treatment with celecoxib and exemestane was generally well tolerated. The majority of toxicities were grades 1 and 2 (Table 3). Toxicities reported with the highest overall frequencies for patients receiving celecoxib and placebo, respectively, were pain (70 vs. $77 \%, P=0.33$ ), arthralgia (32 vs. $43 \%, P=0.16$ ), asthenia (43 vs. $48 \%, P=0.54$ ), and insomnia (39 vs. $49 \%, P=0.20$ ). Patients treated with celecoxib experienced less grade 2 or 3 pain, arthralgia, asthenia, and insomnia and more hypersensitivity reactions (7 vs. $0 \%$ ) and edema (8 vs. $2 \%$ ); all between-group differences were nonsignificant. Gastrointestinal toxicity did not differ in the two arms. One patient with a history of cardiopathy who was treated with celecoxib + exemestane experienced paroxysmal arrhythmia without any cardiac complication.

\section{Discussion}

Results from several clinical trials have demonstrated the antitumor activity of celecoxib in patients with breast cancer in preventive or therapeutic settings [31, 32, 35, 36]. COX-2 inhibitors are thought to inhibit tumors by indirectly affecting estrogen production. Increased prostaglandin $\mathrm{E}_{2}\left(\mathrm{PGE}_{2}\right)$ produced by the activity of the COX-2 enzyme is associated with upregulation of the aromatase enzyme, which in turn leads to increased local estrogen synthesis [29, 37]. These higher estrogen levels stimulate growth and proliferation of a number of breast cancers. By reducing production of $\mathrm{PGE}_{2}, \mathrm{COX}-2$ inhibitors reduce the available estrogen required to maintain the tumors. Therefore, combination therapy with COX-2 inhibitors and AIs was evaluated in several clinical trials [31, 32, 38]. Clinical benefit was achieved in $74 \%$ of patients in a preliminary study of 53 postmenopausal women with histologically confirmed hormone receptor-positive advanced breast cancer treated with exemestane and celecoxib [31].

This study was underpowered because of premature termination and did not demonstrate a PFS difference between treatment groups. Despite the relatively small
Table 3 Toxicity

\begin{tabular}{|c|c|c|c|}
\hline Toxicity & $\begin{array}{l}\text { CTC AE } \\
\text { grade }\end{array}$ & $\begin{array}{l}\text { Celecoxib }+ \\
\text { Exemestane, } \\
n(\%)\end{array}$ & $\begin{array}{l}\text { Placebo }+ \\
\text { Exemestane, } \\
n(\%)\end{array}$ \\
\hline Alopecia & 1 & $3(4)$ & $2(2)$ \\
\hline Anorexia & 1 & $1(1)$ & $0(0)$ \\
\hline \multirow[t]{3}{*}{ Arthralgia } & 1 & $10(13)$ & $13(16)$ \\
\hline & 2 & $9(12)$ & $15(18)$ \\
\hline & 3 & $5(7)$ & $8(10)$ \\
\hline \multirow[t]{3}{*}{ Asthenia } & 1 & $17(23)$ & $16(19)$ \\
\hline & 2 & $14(19)$ & $23(28)$ \\
\hline & 3 & $1(1)$ & $1(1)$ \\
\hline Cardiac arrhythmia & 3 & $1(1)^{\mathrm{a}}$ & $0(0)$ \\
\hline \multirow[t]{2}{*}{ Dysesthesia } & 1 & $1(1)$ & $1(1)$ \\
\hline & 2 & $0(0)$ & $1(1)$ \\
\hline Dyspnea & 1 & $0(0)$ & $1(1)$ \\
\hline \multirow[t]{3}{*}{ Edema } & 1 & $5(7)$ & $5(6)$ \\
\hline & 2 & $6(8)$ & $2(2)$ \\
\hline & 3 & $0(0)$ & $0(0)$ \\
\hline \multirow[t]{2}{*}{ Gastrointestinal difficulties } & 1 & $0(0)$ & $1(1)$ \\
\hline & 2 & $3(4)$ & $2(2)$ \\
\hline \multirow[t]{2}{*}{ Hepatic cytolysis } & 1 & $0(0)$ & $2(2)$ \\
\hline & 2 & $1(1)$ & $0(0)$ \\
\hline \multirow[t]{3}{*}{ Hypersensitivity reaction } & 1 & $1(1)$ & $3(3)$ \\
\hline & 2 & $3(4)$ & $0(0)$ \\
\hline & 3 & $2(3)$ & $0(0)$ \\
\hline \multirow[t]{2}{*}{ Insomnia } & $1-2$ & $24(32)$ & $39(47)$ \\
\hline & 3 & $5(7)$ & $2(2)$ \\
\hline \multirow[t]{2}{*}{ Mucositis } & 1 & $3(4)$ & $1(1)$ \\
\hline & 2 & $1(1)$ & $0(0)$ \\
\hline \multirow[t]{3}{*}{ Pain } & 1 & $13(18)$ & $12(14)$ \\
\hline & 2 & $28(38)$ & $30(36)$ \\
\hline & 3 & $11(15)$ & $22(27)$ \\
\hline \multirow[t]{3}{*}{ Rash } & 1 & $5(7)$ & $6(7)$ \\
\hline & 2 & $2(3)$ & $4(5)$ \\
\hline & 3 & $4(5)$ & $2(2)$ \\
\hline Visual difficulties & 1 & $0(0)$ & $1(1)$ \\
\hline Weight decrease & 1 & $0(0)$ & $1(1)$ \\
\hline Weight increase & 3 & $0(0)$ & $1(1)$ \\
\hline
\end{tabular}

$C T C A E$ common toxicity criteria for adverse events

${ }^{a}$ Observed in a patient with a history of arrhythmia

numbers of patients remaining after premature termination of the study (median time on study treatment was 6 months), we elected to examine the effects of the combination therapy on PFS in 2 subpopulations. Previous preliminary evaluations demonstrated improved antitumor response in patients with breast cancer treated with exemestane and celecoxib for $>3$ months [32]. In the current study, the cohort of patients who were treated for $\geq 3$ months before trial termination had a PFS that was 
numerically better for patients treated with celecoxib compared with placebo (12.2 vs. 9.8 months, respectively; $P=0.09$ ). However, this difference was not significant, nor was it observed in the entire study population. Among tamoxifen-resistant patients (i.e., those who developed metastatic disease during therapy with tamoxifen or within 12 months after completion of tamoxifen treatment), PFS was significantly greater in patients who received the combination therapy for $\geq 3$ months ( 8.4 vs. 4.7 months with placebo, $P=0.019$ ). Several potential explanations exist for these isolated improvements. Could this subgroup potentially consist of patients who lost hormone sensitivity during tamoxifen treatment and thus no longer responded to endocrine therapy alone (including AIs)? Although this may explain the lower median PFS for patients treated with AIs alone in the tamoxifen-resistant group compared with the broader trial (4.7 vs. 9.8 months, respectively), it would still reinforce an added antitumor activity of celecoxib in the advanced breast cancer setting. Or, is COX-2 overexpression highly variable but more specific in the relatively aggressive tamoxifen-resistant tumors? This also raises the potential question of whether to initiate "targeted" use of anti-COX-2 treatments focused on COX-2 overexpressing tumors. Although these subgroup analyses were not intended in the original study design, the preliminary results should be considered in designing future studies.

In this study, concomitant treatment with celecoxib and exemestane was well tolerated. Patients treated with the combination had less pain, arthralgia, and insomnia, all of which have been observed in previous studies with AIs [31, 39]. However, in December 2004, cardiovascular toxicity concerns led the National Cancer Institute to terminate a study investigating the use of celecoxib to prevent colon polyps [34, 40]. Subsequently, the US Food and Drug Administration (FDA) issued a Public Health Advisory regarding continued use of COX-2 inhibitors [41], and studies for several indications, including cancer prevention, arthritis, and osteoarthritis, were prematurely halted. Later, an FDA advisory committee recommended continued use of COX-2 inhibitors with safety warnings highlighting the increased risk for cardiovascular toxicity [42]. Because the cardiotoxicity associated with COX-2 inhibitors appears to be progressive and cumulative, it is not surprising that it was not observed during this study, with the exception of arrhythmia in a patient with a history of cardiopathy. The median duration of treatment (6 months) of the small population here was substantially shorter than the 2.83.1 years of follow-up in the Adenoma Prevention With Celecoxib study [34].

The hypothesis of the current study was that the use of AIs concomitantly with inhibitors of promoter II of the cytochrome P450 (CYP) 19 gene could be clinically relevant because the two drugs may act synergistically.
However, considering the known cardiotoxicity risk associated with COX-2 inhibitors, another strategy is to focus on different regulators of aromatase expression, such as the nuclear receptor liver receptor homolog-1 (LRH-1) [43, 44] A major advantage to this concept is that CYP19 uses $\geq 9$ different promoters that are at least partially tissue specific [45]. Thus, the strategy of targeting CYP19 promoters in breast cancer tissue has the potential to be highly tolerated.

Although the results from this study did not show a significant benefit for the combination treatment in patients with metastatic breast cancer, this regimen should be the subject of further evaluation with adequate cardiac monitoring. To further support this proposal, a meta-analysis is in preparation that will pool results from three trials using COX-2 inhibitors in combination with exemestane in patients with metastatic breast cancer to allow evaluation of efficacy of this treatment regimen in a sufficiently large patient population.

Acknowledgments This study was supported by a grant from Pfizer Inc. The authors wish to thank Gerard P. Johnson, $\mathrm{PhD}$, and Janet Stead, BM, BS, of Complete Healthcare Communications, Inc., for writing and editorial assistance provided on behalf of Pfizer Inc and to thank the investigators: S. Labadie-Lacourtoisie (Centre Paul Papin, Angers, France), D. Allouache (Centre Francois Baclesse, Caen, France), T. Bachelot (Centre Léon Bérard, Lyon, France), J.-C. Barats (Hôpitaux Civils de Colmar, Colmar, Cedex, France), C. Becuwe (Centre d'Oncologie de Gentilly, Nancy, France), E. Blot (Centre Henri Becquerel, Rouen, France), E. Brain (Centre René Huguenin, Saint-Cloud, France), P. Chinet-Charrot (Centre Henri Becquerel, Rouen, France), O. Collard (Institut de Cancérologie de la Loire, Saint Priest en Jarrest, France), J. Crétin (Clinique Valdegour, Nîmes, France, and Clinique Bonnefon, Alès, France), G. De Rauglaudre (Clinique Sainte Catherine, Avignon, France), P. De Saint Hilaire (Hôpital de la Croix-Rousse, Lyon, France), M. Debled (Institut Bergonié, Bordeaux, France), T. Delozier (Centre Francois Baclesse, Caen, France), R. Delva (Centre Paul Papin, Angers, France), B. Duvert (Centre Hospitalier Général, Lons-le-Saunier, France), M. Edel (Hôpital du Hasenrain, Mulhouse, France), J.-M. Ferrero (Centre Antoine Lacassagne, Nice, France), G. Freyer (Centre Hospitalier Lyon Sud, Pierre-Bénite, France), J.-P. Guastalla (Centre Léon Bérard, Lyon, France), C. Guillemet (Centre Henri Becquerel, Rouen, France), C. Hanzen (Centre Henri Becquerel, Rouen, France), A.-C. Hardy-Bessard (Clinique Armoricaine de Radiologie, Saint Brieuc, France), J.-P. Jacquin (Clinique de la Digonnière, Saint-Etienne, France), S. Kirscher (Clinique Sainte Catherine, Avignon, France), J.-M. Ladonne (Centre Henri Becquerel, Rouen, France), R. Largillier (Centre Antoine Lacassange, Nice, France), B. Leduc (Centre Hospitalier Général, Brive-la-Gaillarde, France), B. Levaché (Polyclinique Francheville, Périgueux, France), E. Levy (Hôpital Européen Georges Pompidou, Paris, France), L. Mauriac (Institut Bergonié Regional Cancer Centre, Bordeaux, France), L. Mefti (Centre René Huguenin, Sant-Cloud, France), D. Mille (Institut de Cancérologie de la Loire, Saint Priest en Jarrest, France), S. OddouLagranière (Centre Hospitalier intercommunal des Alpes du Sud, Gap, France), D. Piot (Clinique des Ormeaux-Vauban, Le Havre, France), F. Priou (Centre Hospitalier Départemental, La Roche sur Yon, France), P. Romestaing (Centre Hospitalier Lyon Sud, PierreBénite, France), D. Solub (Hôpital Fontenoy, Chartres, France), P. Soulie (Centre Paul Papin, Angers, France), V. Trillet-Lenoir (Centre Hospitalier Lyon Sud, Pierre-Bénite, France), B. Valenza 
(Centre Hospitalier, Draguignan, France), and C. Veyret (Centre Henri Becquerel, Rouen, France).

\section{References}

1. American CancerSociety (2006) Cancer facts and figures 2006. American Cancer Society, Atlanta

2. Parkin DM, Bray F, Ferlay J, Pisani P (2005) Global cancer statistics, 2002. CA Cancer J Clin 55:74-108

3. Crown J, Dieras V, Kaufmann M et al (2002) Chemotherapy for metastatic breast cancer-report of a European expert panel. Lancet Oncol 3:719-727. doi:10.1016/S1470-2045(02)00927-0

4. von Minckwitz G (2006) Evidence-based treatment of metastatic breast cancer-2006 recommendations by the AGO Breast Commission. Eur J Cancer 42:2897-2908. doi:10.1016/j.ejca. 2006.06.033

5. Wilcken N, Hornbuckle J, Ghersi D (2003) Chemotherapy alone versus endocrine therapy alone for metastatic breast cancer. Cochrane Database Syst Rev CD002747

6. Beslija S, Bonneterre J, Burstein H et al (2007) Second consensus on medical treatment of metastatic breast cancer. Ann Oncol 18:215-225. doi:10.1093/annonc/mdl155

7. Bonneterre J, Buzdar A, Nabholtz JM et al (2001) Anastrozole is superior to tamoxifen as first-line therapy in hormone receptor positive advanced breast carcinoma. Cancer 92:2247-2258. doi:10.1002/1097-0142(20011101)92:9<2247::AID-CNCR1570 $>3.0 . \mathrm{CO} ; 2-\mathrm{Y}$

8. Mouridsen H, Gershanovich M, Sun Y et al (2003) Phase III study of letrozole versus tamoxifen as first-line therapy of advanced breast cancer in postmenopausal women: analysis of survival and update of efficacy from the International Letrozole Breast Cancer Group. J Clin Oncol 21:2101-2109. doi:10.1200/ JCO.2003.04.194

9. Nabholtz JM, Buzdar A, Pollak M et al (2000) Anastrozole is superior to tamoxifen as first-line therapy for advanced breast cancer in postmenopausal women: results of a North American multicenter randomized trial Arimidex Study Group. J Clin Oncol $18: 3758-3767$

10. Paridaens RJ, Dirix LY, Beex LV et al (2008) Results of a randomized clinical trial comparing exemestane with tamoxifen as first-line hormonal treatment of metastatic breast cancer in postmenopausal women: a phase III study conducted by the EORTC Breast Cancer Cooperative Group. Breast Cancer Res Treat (in press)

11. Schrey MP, Patel KV (1995) Prostaglandin E2 production and metabolism in human breast cancer cells and breast fibroblasts. Regulation by inflammatory mediators. $\mathrm{Br} \mathrm{J}$ Cancer 72: 1412-1419

12. Huang M, Stolina M, Sharma S et al (1998) Non-small cell lung cancer cyclooxygenase-2-dependent regulation of cytokine balance in lymphocytes and macrophages: up-regulation of interleukin 10 and down-regulation of interleukin 12 production. Cancer Res 58:1208-1216

13. Chang S-H, Liu CH, Conway R et al (2004) Role of prostaglandin E2-dependent angiogenic switch in cyclooxygenase 2-induced breast cancer progression. Proc Natl Acad Sci USA 101:591-596. doi:10.1073/pnas.2535911100

14. Tsujii M, DuBois RN (1995) Alterations in cellular adhesion and apoptosis in epithelial cells overexpressing prostaglandin endoperoxide synthase 2. Cell 83:493-501. doi:10.1016/0092-8674 (95)90127-2

15. Tsujii M, Kawano S, Tsuji S et al (1998) Cyclooxygenase regulates angiogenesis induced by colon cancer cells. Cell 93:705716. doi:110.1016/S0092-8674(00)81433-6
16. O’Neill GP, Ford-Hutchinson AW (1993) Expression of mRNA forcyclooxygenase- 1 and cyclooxygenase- 2 in human tissues. FEBS Lett 330:156-160. doi:10.1016/0014-5793(93)80263-T

17. Eberhart CE, Coffey RJ, Radhika A et al (1994) Up-regulation of cyclooxygenase 2 gene expression in human colorectal adenomas and adenocarcinomas. Gastroenterology 107:1183-1188

18. Parrett M, Harris R, Joarder F, Clausen K, Robertson F (1997) Cyclooxygenase-2 gene expression in human breast cancer. Int $\mathrm{J}$ Oncol 10:503-507

19. Liu CH, Chang S-H, Narko K et al (2001) Overexpression of cyclooxygenase- 2 is sufficient to induce tumorigenesis in transgenic mice. J Biol Chem 276:18563-18569. doi:10.1074/jbc.M0 10787200

20. Howe LR, Chang S-H, Tolle KC et al (2005) HER2/neu-induced mammary tumorigenesis and angiogenesis are reduced in cyclooxygenase-2 knockout mice. Cancer Res 65:10113-10119. doi: 10.1158/0008-5472.CAN-05-1524

21. Harris RE, Namboodiri KK, Farrar WB (1996) Nonsteroidal antiinflammatory drugs and breast cancer. Epidemiology 7:203205. doi:10.1097/00001648-199603000-00017

22. Kucab JE, Lee C, Chen CS et al (2005) Celecoxib analogues disrupt Akt signaling, which is commonly activated in primary breast tumours. Breast Cancer Res 7:R796-R807. doi:10.1186/ bcr1294

23. Basu GD, Pathangey LB, Tinder TL et al (2004) Cyclooxygenase-2 inhibitor induces apoptosis in breast cancer cells in an in vivo model of spontaneous metastatic breast cancer. Mol Cancer Res 2:632-642

24. Alshafie GA, Abou-Issa HM, Seibert K, Harris RE (2000) Chemotherapeutic evaluation of celecoxib, a cyclooxygenase-2 inhibitor, in a rat mammary tumor model. Oncol Rep 7:1377-1381

25. Howe LR, Subbaramaiah K, Patel J et al (2002) Celecoxib, a selective cyclooxygenase 2 inhibitor, protects against human epidermal growth factor receptor 2 (HER-2)/neu-induced breast cancer. Cancer Res 62:5405-5407

26. Lanza-Jacoby S, Miller S, Flynn J et al (2003) The cyclooxygenase-2 inhibitor, celecoxib, prevents the development of mammary tumors in HER-2/neu mice. Cancer Epidemiol Biomarkers Prev 12:1486-1491

27. Higuchi T, Iwama T, Yoshinaga K et al (2003) A randomized, double-blind, placebo-controlled trial of the effects of rofecoxib, a selective cyclooxygenase-2 inhibitor, on rectal polyps in familial adenomatous polyposis patients. Clin Cancer Res 9:4756-4760

28. Steinbach G, Lynch PM, Phillips RKS et al (2000) The effect of celecoxib, a cyclooxygenase- 2 inhibitor, in familial adenomatous polyposis. N Engl J Med 342:1946-1952. doi:10.1056/NEJM2 00006293422603

29. Muller-Decker K, Berger I, Ackermann K et al (2005) Cystic duct dilatations and proliferative epithelial lesions in mouse mammary glands upon keratin 5 promoter-driven overexpression of cyclooxygenase-2. Am J Pathol 166:575-584

30. Pesenti E, Masferrer J, di Salle E (2001) Effect of exemestane and celecoxib alone or in combination on DBMA-induced mammary carcinoma in rats. Breast Cancer Res 69:288 abstract

31. Canney PA, Machin MA, Curto J (2006) A feasibility study of the efficacy and tolerability of the combination of exemestane with the COX-2 inhibitor celecoxib in post-menopausal patients with advanced breast cancer. Eur J Cancer 42:2751-2756. doi: 10.1016/j.ejca.2006.08.014

32. Chow LW, Wong JL, Toi M (2003) Celecoxib anti-aromatase neoadjuvant (CAAN) trial for locally advanced breast cancer: preliminary report. J Steroid Biochem Mol Biol 86:443-447. doi: 10.1016/S0960-0760(03)00355-8

33. Dirix LY, Ignacio J, Nag S et al (2008) Treatment of advanced hormone-sensitive breast cancer in postmenopausal women with 
exemestane alone or in combination with celecoxib. J Clin Oncol 26:1253-1259. doi:10.1200/JCO.2007.13.3744

34. Solomon SD, McMurray JJ, Pfeffer MA et al (2005) Cardiovascular risk associated with celecoxib in a clinical trial for colorectal adenoma prevention. N Engl J Med 352:1071-1080. doi:10.1056/NEJMoa050405

35. Harris R, Beebe-Donk J, Alshafie G (2006) Reduction in the risk of human breast cancer by selective cyclooxygenase-2 (COX-2) inhibitors. BMC Cancer 6:27. doi:10.1186/1471-2407-6-27

36. Rahme E, Ghosn J, Dasgupta K, Rajan R, Hudson M (2005) Association between frequent use of nonsteroidal anti-inflammatory drugs and breast cancer. BMC Cancer 5:159. doi:10.1186/ 1471-2407-5-159

37. Zhao Y, Agarwal VR, Mendelson CR, Simpson ER (1996) Estrogen biosynthesis proximal to a breast tumor is stimulated by PGE2 via cyclic AMP, leading to activation of promoter II of the CYP19 (aromatase) gene. Endocrinology 137:5739-5742. doi: 10.1210/en.137.12.5739

38. Chow LWC, Toi M (2005) Celecoxib anti-aromatase neoadjuvant (CAAN) trial for locally advanced breast cancer. Paper presented at 28th annual San Antonio breast cancer symposium, San Antonio, 8-11 December 2005

39. Dang CT, Dannenberg AJ, Subbaramaiah K et al (2004) Phase II study of celecoxib and trastuzumab in metastatic breast cancer patients who have progressed after prior trastuzumab-based treatments. Clin Cancer Res 10:4062-4067. doi:10.1158/10780432.CCR-03-0463
40. US Food and Drug Administration (2004) FDA statement on the halting of a clinical trial of the Cox-2 inhibitor celebrex. US Food and Drug Administration. Available via http://www.fda.gov/bbs/ topics/news/2004/NEW01144.html. Cited 24 June 2008

41. US Food and Drug Administration (2004) Public Health Advisory: non-steroidal anti-inflammatory drug products (NSAIDs). US Food and Drug Administration. Available via http://www. fda.gov/cder/drug/advisory/nsaids.htm. Cited 24 June 2008

42. US Food and Drug Administration (2005) Analysis and recommendations for Agency action regarding non-steroidal antiinflammatory drugs and cardiovascular risk. US Food and Drug Administration. Available via http://www.fda.gov/cder/drug/ infopage/COX2/NSAIDdecisionMemo.pdf. Cited 24 June 2008

43. Bouchard MF, Taniguchi H, Viger RS (2005) Protein kinase Adependent synergism between GATA factors and the nuclear receptor, liver receptor homolog-1, regulates human aromatase (CYP19) PII promoter activity in breast cancer cells. Endocrinology 146:4905-4916. doi:10.1210/en.2005-0187

44. Zhou J, Suzuki T, Kovacic A et al (2005) Interactions between prostaglandin $\mathrm{E}(2)$, liver receptor homologue-1, and aromatase in breast cancer. Cancer Res 65:657-663

45. Bulun SE, Sebastian S, Takayama K et al (2003) The human CYP19 (aromatase P450) gene: update on physiologic roles and genomic organization of promoters. J Steroid Biochem Mol Biol 86:219-224. doi:10.1016/S0960-0760(03)00359-5 